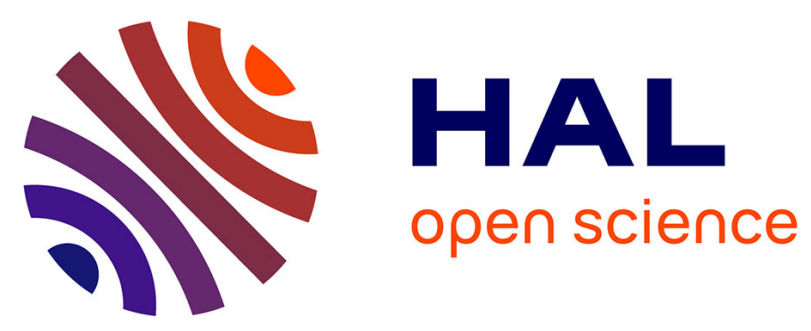

\title{
Water saturation variation in a fire-heated limestone gallery monitored by ERT
}

\author{
Cécile Verdet, Fabien Salmon, Colette Sirieix, Delphine Lacanette
}

\section{To cite this version:}

Cécile Verdet, Fabien Salmon, Colette Sirieix, Delphine Lacanette. Water saturation variation in a fire-heated limestone gallery monitored by ERT. Geophysical Journal International, 2021, 227 (1), pp.660-668. 10.1093/gji/ggab239 . hal-03406795

\section{HAL Id: hal-03406795 \\ https://hal.science/hal-03406795}

Submitted on 28 Oct 2021

HAL is a multi-disciplinary open access archive for the deposit and dissemination of scientific research documents, whether they are published or not. The documents may come from teaching and research institutions in France or abroad, or from public or private research centers.
L'archive ouverte pluridisciplinaire HAL, est destinée au dépôt et à la diffusion de documents scientifiques de niveau recherche, publiés ou non, émanant des établissements d'enseignement et de recherche français ou étrangers, des laboratoires publics ou privés. 


\section{Water saturation variation in a fire-heated limestone gallery monitored by ERT}

Cécile Verdet ${ }^{1}$, Fabien Salmon ${ }^{1}$, Colette Sirieix ${ }^{1}$, and Delphine Lacanette ${ }^{1}$

${ }^{1}$ University of Bordeaux, CNRS, Arts et Metiers Institute of Technology, Bordeaux INP, INRAE, I2M Bordeaux, F-33400 Talence, France

Corresponding author: Cécile Verdet (cecile.verdet@u-bordeaux.fr)

Abbreviated title: ERT-monitored saturation of fire-heated limestone 


\section{Abstract}

Water migration within the rock mass during a fire has not yet been studied. Here, an innovative high resolution micro-ERT method is developed at a centimetric scale to measure this phenomenon. The method is two-step based: first, a correction of the electrode effect, and second, the correction of resistivity for rapid variations in temperature with high values. Water migration is successfully described within the wall of an underground limestone quarry with three phases: from fire ignition to $36 \mathrm{~min}$, the surface dries to a 3-cm depth and a higher saturated layer forms deeper than $0.10 \mathrm{~m}$; from $36 \mathrm{~min}$ to 46 min (fire supply stops), the rock dries out and water migrates from deeper parts of the rock wall, deeper than $20 \mathrm{~cm}$, toward the surface; finally, after fire extinction, the water migrates through a readjustment phase until it returns to its initial state.

Keywords: Electrical resistivity tomography (ERT), Heat generation, Heat flow, Rapid time variations

\section{Introduction}

Research on heated walls looks partly at the thermal processes within walls during fires (Zhao \& Kruppa 2004, Nguyen et al. 2009, Nassif et al. 2014, Ozguven \& Ozcelik 2014, Shao et al. 2016). These thermal processes are dependent on other physical parameters (for instance water content) which can be considered in various models (Nguyen et al. 2009, Nassif et al. 2014) through the usual physical coefficients, such as specific heat or thermal conductivity. Beyond those thermal phenomena, the other physical processes that takes place during a fire within walls are still rather unknown, while they are known to change wall properties (Wang et al. 2019). Indeed, most of studies focus on heated samples and do not consider phenomena at the scale of a wall. For instance, researches done on heated concrete samples (Jansson \& Boström 2009, der Heijden et al. 2012, Mindeguia et al. 2015, Choe et al. 2019) showed that water migrates in samples, inducing an over-pressure (moisture clog phenomena) which could explain concrete spalling. Other studies on heated rocks showed changes in physical and chemical properties, like for instance strain due to sudden changes in temperature (Shao et al. 2016, Wang et al. 2019), matrix decay by clay minerals alteration (Hajpal \& Török 2004) and changes in color from original colon to red or black (McCabe et al. 2010). Whereas those studies handle phenomena in samples, our study concerns water migration in a wall during a fire. The difference in scale involves significant deviations in the process.

In particular, the study investigates for the first time the action of a localized fire in a limestone gallery on water saturation variations in the rock mass. Such a study can be applied in various fields, like fires in 
tunnels (Abraham \& Dérobert 2003), mines (Zhao \& Kruppa 2004, Wessling et al. 2008), limestone monuments (e.g. Notre-Dame of Paris, Deldicque \& Rouzaud (2020)) or even natural caves (Carrancho et al. 2009, Salmon et al. 2019). Fires were ignited in a quarry situated in south-west France (Lacanette et al. 2017, Salmon et al. 2020b), aiming at understanding the impact of Paleolithic fires on the ChauvetPont-d'Arc Cave walls (Ferrier et al. 2017, Salmon et al. 2020a).

The main challenge of this study is to assess water saturation variation during fires using Electrical Resistivity Tomography (ERT) measurements. Indeed, two main difficulties appear: (1) the ERT set-up needs to be small to observe centimetric changes, and (2) the temperature increases quickly. The first difficulty was resolved in Verdet et al. (2018) by developing a small-scale ERT tool with centimetric electrode spacing and a numerical correction of an electrode effect. The second difficulty is addressed in the present paper. The ERT measurements need to be adjusted to a single temperature to observe water migration variation, while the rock temperature remains lower than $86.6^{\circ} \mathrm{C}$. The proposed dynamic temperature correction aims at considering both (i) the high temperature in the rock and (ii) the adjustment to the ERT measurement duration. Once the correction has been applied, the water content of the rock mass can be monitored during the fire.

\section{Materials and Methods}

The limestone quarry is situated in south-west France, near Bordeaux (Figure 1.a). The surrounding of the quarry is a known karstic site with many kinds of alterations as described by Dubois et al. (2011) including a lot of known caves among which the largest known cave in the Gironde department and a gallery development of more than $8.5 \mathrm{~km}$ (Grand-Antoine Cave, GESA, 2015). The quarry extends through Rupelian limestone (28.1-33.9 Ma) which presents high vertical and horizontal variations in lithology (Le Pochat \& Sellier 1980). The limestone is mainly bioclastic and presents a tendency to crumble and a loose cementation with a porosity measured up to $41 \%$. The quarry limestone presents high variations in depth but measurements achieved on surface samples showed that the modulus of elasticity was approximately $2.5 \mathrm{GPa}$ at $20^{\circ} \mathrm{C}$ and the Poisson ratio was of 0.3 (Lacanette et al. 2017). Within the quarry, the limestone presents a high variability (Verdet et al. 2018, Salmon et al. 2020b). Consequently, the ERT profile samples three different facies (Figure 1.b), top to bottom: $3 \mathrm{~b}$ (soft and fine limestone with shells and ferrous oxide inclusions at the bottom), $3 c$ (harder and coarse limestone with ferrous oxide inclusion) and $3 \mathrm{~d}$ (soft and fine shelly limestone). The dip of the limestone is subhorizontal, $6^{\circ} \mathrm{NE}$. 
This section presents the instrumentation set-up and the thermal model used to compute the temperature at every point of the studied wall.

\subsection{Thermocouples and micro-ERT set-up}

To acquire the ERT measurements, a micro-ERT profile was also implemented (Figure 1.a) in the fire room (fire profile). It consists of a set-up containing 24 stainless steel rod electrodes with $4 \mathrm{~cm}$ electrode spacing, for a total length of $92 \mathrm{~cm}$ (Figure 2.a). The electrodes, with a diameter of $0.4 \mathrm{~cm}$, were driven to a depth of $1.5 \mathrm{~cm}$. Measurements were carried out with the fast resistivity meter Syscal Pro from Iris Instrument using the dipole-dipole array. The data points were measured along an oblique line running from the first electrode (bottom) toward the last one (top) (Figure 2.a). The cable linking the electrodes to the measurement unit was designed to resist high temperatures, by covering the cable with an insulanting material (Isofrax ${ }^{\circledR}$, in white in Figure 1.b).

In order to observe the temperature variations, the instrumentation set-up consists in eight thermocouples, located within the quarry wall and carefully placed at various depths, from $0.5 \mathrm{~cm}$ to $4.5 \mathrm{~cm}$ (Figure $2 . \mathrm{b}$ and Table 1 ) and at three different heights along the micro-ERT profile (Figure 2.a) (Verdet et al. 2018, Salmon et al. 2020b). The micro-ERT profile is located at $1.2 \mathrm{~m}$ from the center of the 80-centimeter diameter hearth.

Table 1: Depth of thermocouples

\begin{tabular}{|l|ll|ll|ll|}
\hline Line P3 & T4: & $1.5 \mathrm{~cm}$ & & & T5: & $3.5 \mathrm{~cm}$ \\
\hline Line P2 & T1: & $1 \mathrm{~cm}$ & T2: & $2 \mathrm{~cm}$ & T3: & $4 \mathrm{~cm}$ \\
\hline Line P1 & T6: & $0.5 \mathrm{~cm}$ & T7: & $1.5 \mathrm{~cm}$ & T8: & $4.5 \mathrm{~cm}$ \\
\hline
\end{tabular}




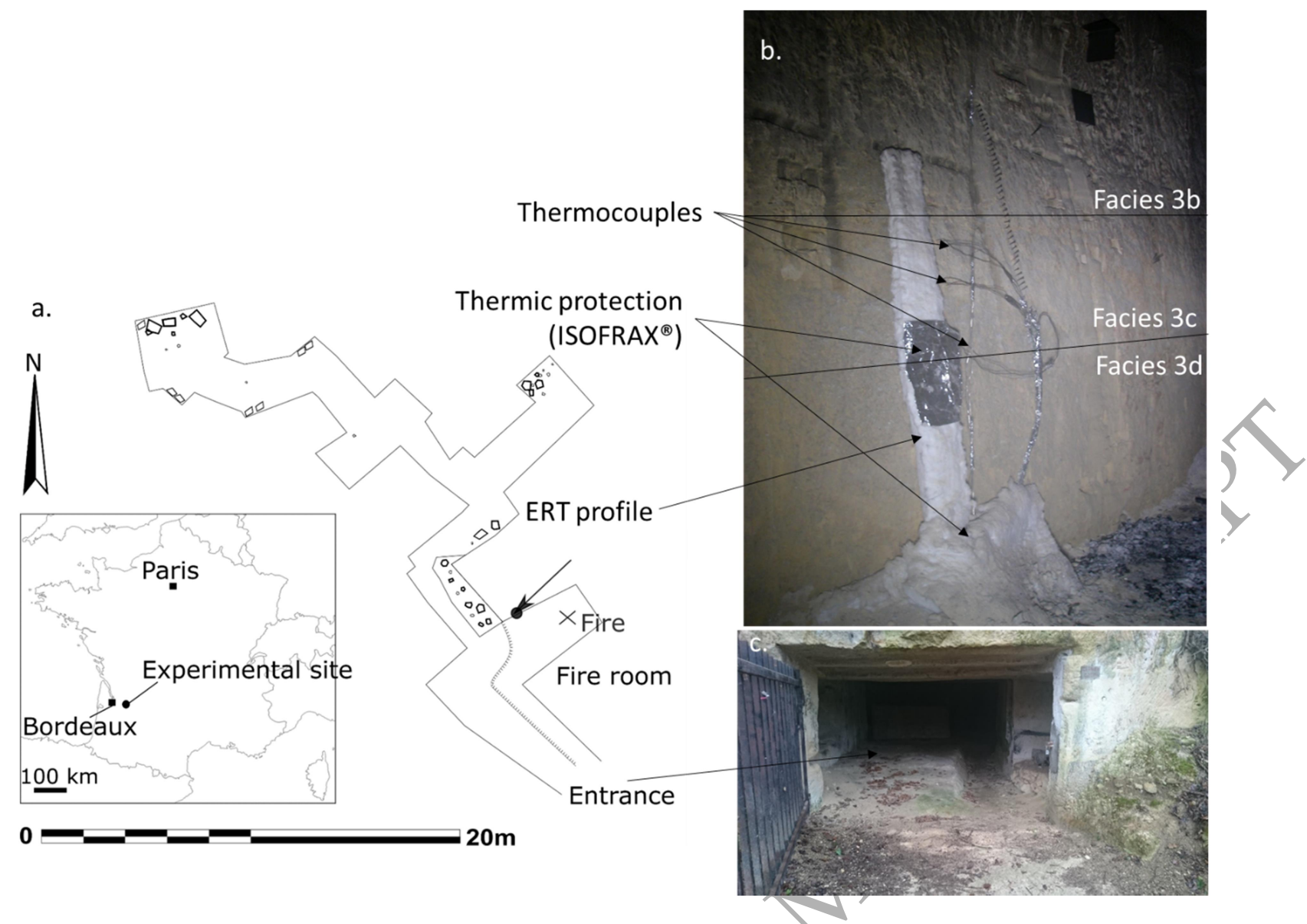

Figure 1: (a) Experimental site location and cut-away view of the quarry with the location of the ERT profile (b) the set-up protected by a thermal protection, thermocouples and geological facies cut by the micro-ERT profile (c) view of the quarry entrance. 
a.

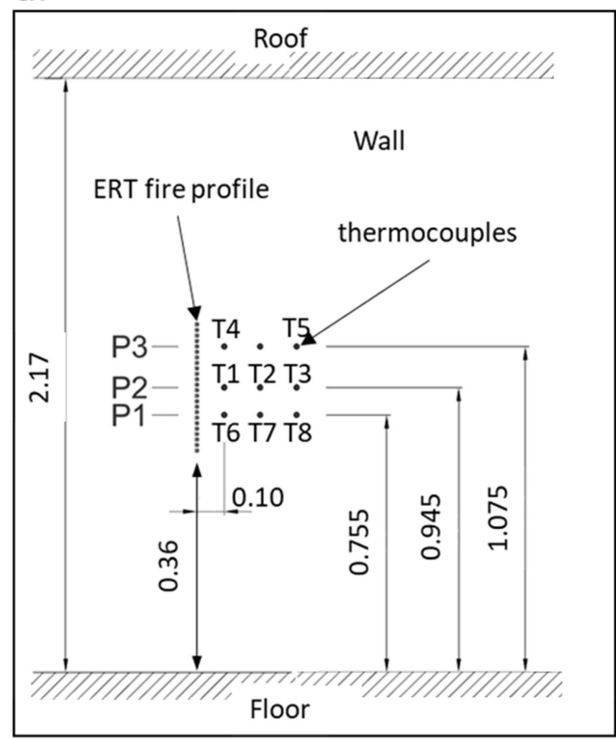

Front view of the ERT profile b.

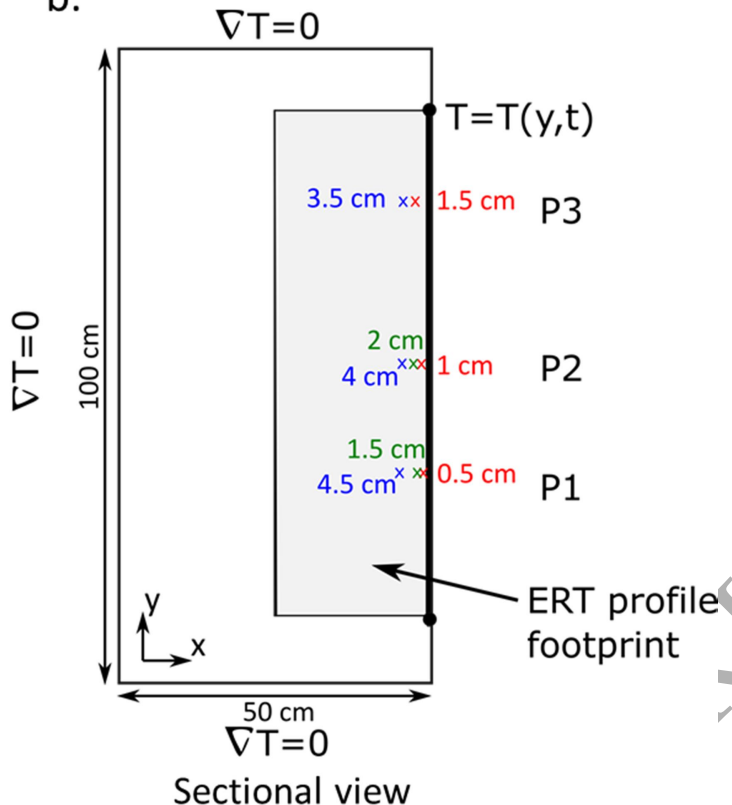

Figure 2: ERT and thermocouple set-up (a) Front view of the ERT fire profile and location of the thermocouples in the wall, (b) Sketch presenting the projection of the thermocouple depths on a sectional view and boundary conditions in the temperature model.

In order to carry out the inversion process of the measured apparent resistivities, a first correction must be made. Indeed, as shown by Verdet et al. (2018), the electrode embedment to electrode spacing ratio is greater than $20 \%$, so there is an electrode effect. Therefore, all the inversions were performed using an EEP (Equivalent Electrode Point) at $73 \%$ of the electrode depth (Verdet et al. 2018). The inversion was achieved with the BERT 2.1 package (Günther et al. 2006) using the L1-norm optimization method, a Gauss-Newton scheme, and a regularization parameter set to 20.

\subsection{Modeling of the wall temperature}

A dynamic correction of micro-ERT measurements requires the wall temperature. Since the thermocouples only provided the information at some locations (Figure 2), a mathematical modeling of the wall temperature had to be set up. Heat transfer in rock essentially corresponds to thermal diffusion, which is mathematically described by the heat equation (1)

$$
\frac{\partial T}{\partial t}=D\left(\frac{\partial^{2} T}{\partial x^{2}}+\frac{\partial^{2} T}{\partial y^{2}}\right)
$$

where $T$ is the temperature and $D$ is the thermal diffusivity. A 2D calculation based on a rectangular domain is convenient to solve this problem. Indeed, the hypothesis about the negligibility of the local 
variation of the temperature in the third direction appears reliable as shown later in the paper below with the comparison between this model and the experimental data. A Dirichlet boundary condition is applied to the line corresponding to the wall surface while zero Neumann boundary conditions are applied to the other three boundaries (Figure 2.b). Note that the temperature imposed on the wall surface varies with time since the energy released by the fire evolved. The Neumann boundary conditions $(\nabla T=\mathbf{0})$ is far enough from the zone of interest to have no impact on the simulation results (Figure 2.b). A numerical simulation of the fire (Salmon et al., 2019) is not accurate enough to rely on the calculation of the wall surface temperature. In addition, only measurements of the air temperature were achieved, so the temperature of the surface of the wall is not directly accessible. Figure 3 presents the air temperature measured at different heights during the fire. They are located $60 \mathrm{~cm}$ in front of the profile presented in Figure 2.
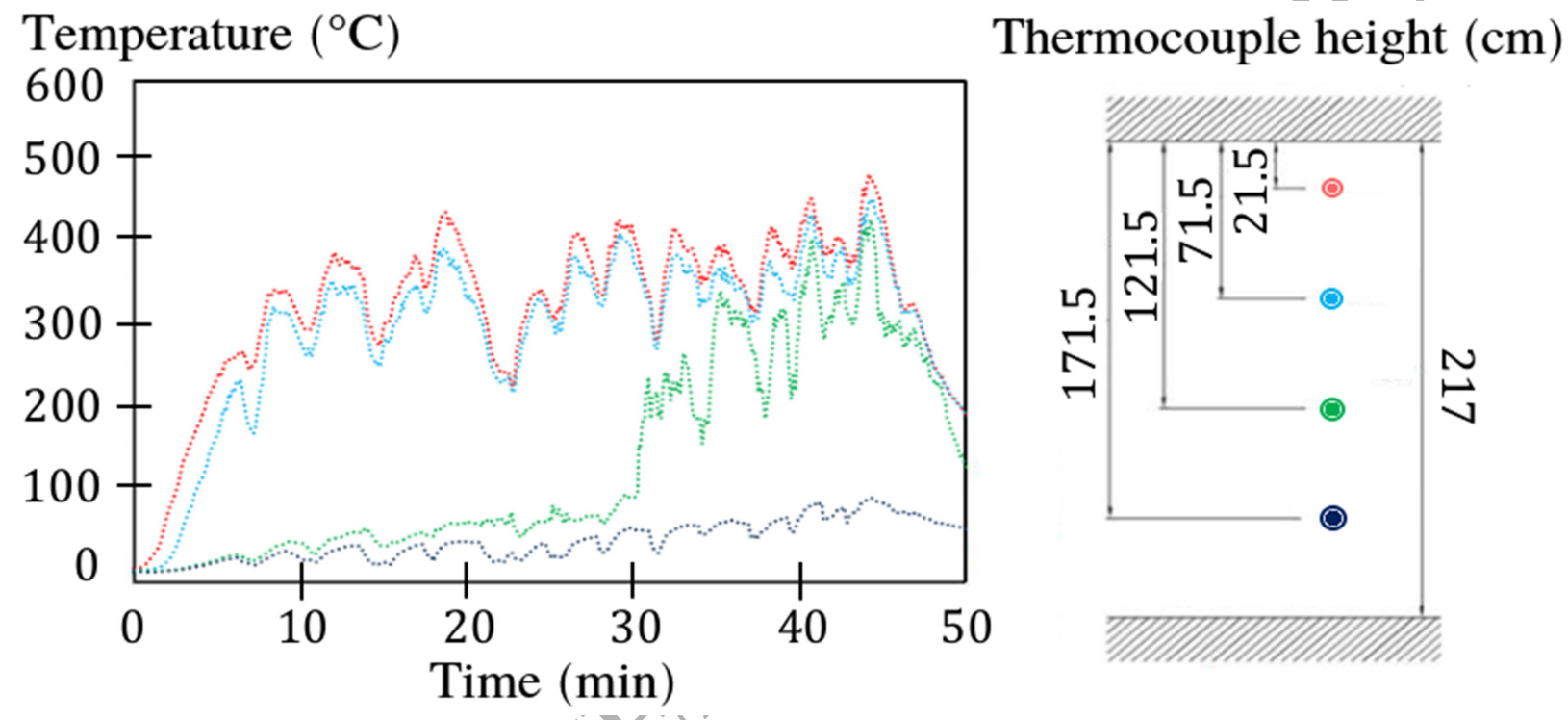

Figure 3 : Gas temperature measured $60 \mathrm{~cm}$ in front of the profile presented in figure 2 at different heights.

Furthermore, the thermal diffusivity may change over the first few centimeters due to variations in porosity or the degree of saturation. Therefore, due to missing information, the problem cannot be directly solved. The approach then consists in estimating the thermal diffusivity and the surface temperature that ensure consistent results with the experimental data. The resolution of the heat equation is performed on an exponential mesh: the first cell is $2 \mathrm{~mm}$ wide, the common ratio is 1.1 and all the cells are $5 \mathrm{~mm}$ long. 
Figure 4 shows that the temperature grows up from 11 to $86.6^{\circ} \mathrm{C}$ near the surface of the wall at $1 \mathrm{~cm}$ depth, whereas it grows up only to $35^{\circ} \mathrm{C}$ at $4.5 \mathrm{~cm}$. It is however worth noting that almost 2 hours after ignition, the rock temperature is still greater than $30^{\circ} \mathrm{C}$ at a depth of $4.5 \mathrm{~cm}$. The fire thus persistently impacted rock in depth. Note that thermocouples $T 1$ and $T 6$ sometimes had to measure the temperature of gases rather than that of the rock (after $4300 \mathrm{~s}$ and between 2000 and $3500 \mathrm{~s}$ respectively). This issue results from the location of T1 and T6 which were very close to the surface of the wall (Figure 2). For instance, we observed at the end of the experimentation that thermocouple $T 1$ was in the air and not within the wall. It is probably the same for T6 during the fire.

With the likely thermal diffusivity and surface temperature, the numerical computation reaches relevant temperatures (Figure 4). The average error $\varepsilon=\frac{\left|T_{\exp }-T_{\text {mod }}\right|}{T_{\exp }}$ is inferior to $5 \%$ for all the thermocouples. We consider that the calculated temperatures are satisfactory over the first centimeters of the wall. Since the temperature remains low deeper in the rock mass, the error should stay low eyerywhere. The micro-ERT measurements will thus be corrected for the temperature field calculated through this modeling.
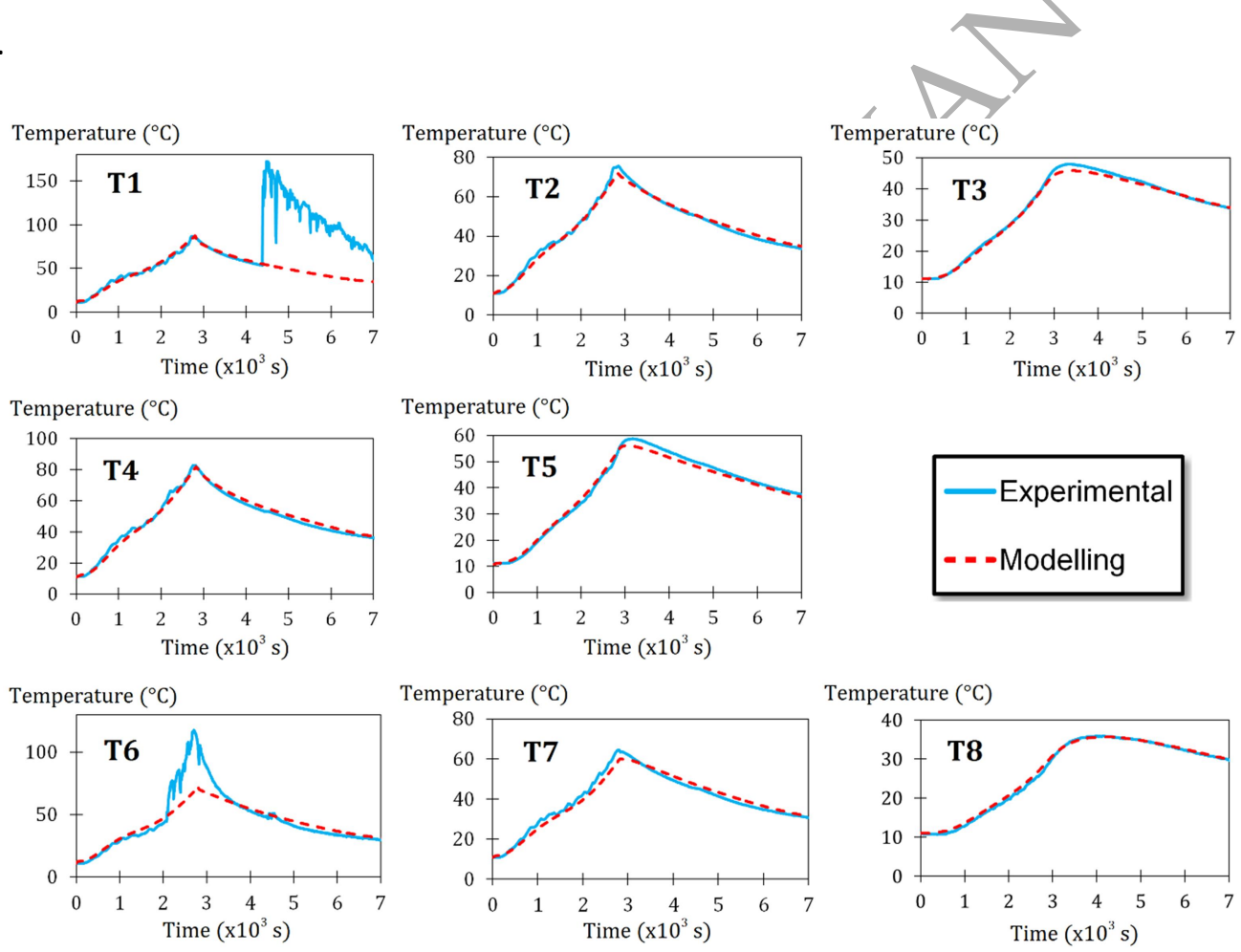

Figure 4: Comparison between experimental data and temperature modeling for the eight thermocouples (Figure 2). 
As the temperature remains higher than at the initial state, to a depth of at least $4.5 \mathrm{~cm}$, a temperature effect correction is proved to be mandatory.

\subsection{ERT high-temperature correction}

Electrical resistivity data are known to be affected by the temperature of rock (Whitney \& Briggs 1897, Campbell et al. 1948, Grolier et al. 1991). As the temperature varies, a correction is applied to the datasets. The general equation is given as $\rho_{T_{r e f}}=\frac{1}{f_{T}} * \rho_{T}$ with $\rho_{T_{r e f}}$ the resistivity at the reference temperature, $\rho_{T}$ the resistivity at temperature $T$ and $f_{T}$ the calculated correction factor (Besson et al. 2008). This last factor can be calculated using different models: ratio (Keller \& Frischknecht 1966), exponential (corrected by Corwin \& Lesch (2005) from Sheets \& Hendrickx (1995), or Besson et al., (2008); Ma et al., (2011); Wells, (1978)), power (Besson et al. 2008) or polynomial (Rhoades et al. 1977, Or \& Wraith 1999).

Usually, the temperature effect correction factor has a validity range from 3 to $47^{\circ} \mathrm{C}$. In the quarry, the maximum temperature measured in rock was $86.6^{\circ} \mathrm{C}$, out of the validity range. Karato \& Wang (2013) showed that electrical conductivity exponentially grows with temperature, so we adopted an exponential model. A comparison between the experimental data from Richards (1969) with the existing exponential models shows that the lowest RMS (root mean square) is found for the Corwin \& Lesch (2005) model (Genelle et al. 2012). Therefore, among existing $f_{T}$ calculation models, we chose the exponential model (2) from Corwin \& Lesch (2005), with a reference temperature of $25^{\circ} \mathrm{C}$ :

$$
f_{T}=0,4470+1,4034 * e^{\frac{-T}{26,815}}
$$

with $T$ the temperature at the time of measurement.

\subsection{Dynamic correction of the high temperature effect}

The temperature taken for the correction is usually a single estimated value of the temperature for each depth (Hayley et al. 2010, Xu et al. 2015). For this study, one ERT acquisition took about 5 min for 349 data points. Within those five minutes, the temperature may have varied too much to take a mean temperature for each depth (ex: Figure 5.c). Therefore, each inverted resistivity data point had to be corrected with the temperature at its position and time of measurement.

The correction calculation was done in three main steps: 
1. The survey time and the position of each quadrupole were noted. However, the number of apparent resistivity datum points (measured resistivity) was lower (349) than that of the inversion cells (inverted resistivity). Therefore, for each cell, we applied the time of the closest datum point of the cell barycenter. A time matrix was created, linking inverted resistivity cells to a time.

2. A temperature matrix was created from the calculated temperature (equation 1) and the time matrix. The output gives the temperature at the time and location of each inverted resistivity cell. For instance, Figure 5.c displays the calculated temperature at $46 \mathrm{~min}$ after ignition. The temperature matrix is associated with the inverted resistivity matrix, linking a single temperature value to each cell of the inversion mesh.

3. The inverted resistivity in each cell of the resistivity mesh is corrected for the temperature effect using equation 2 (thus with a reference temperature of $25^{\circ} \mathrm{C}$ ), with the temperature at the measurement time $(\mathrm{t})$ given for each point by the temperature matrix. In this process, the mesh used for the temperature modeling is more refined than that of the resistivity inversion (see §2.2).

a.

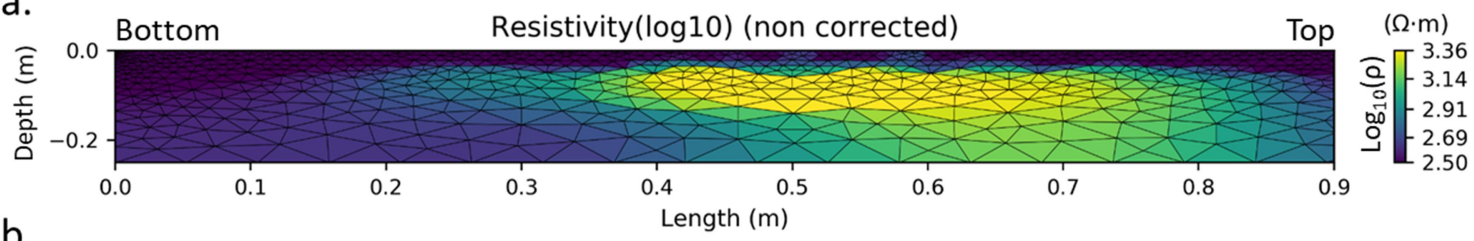

b.

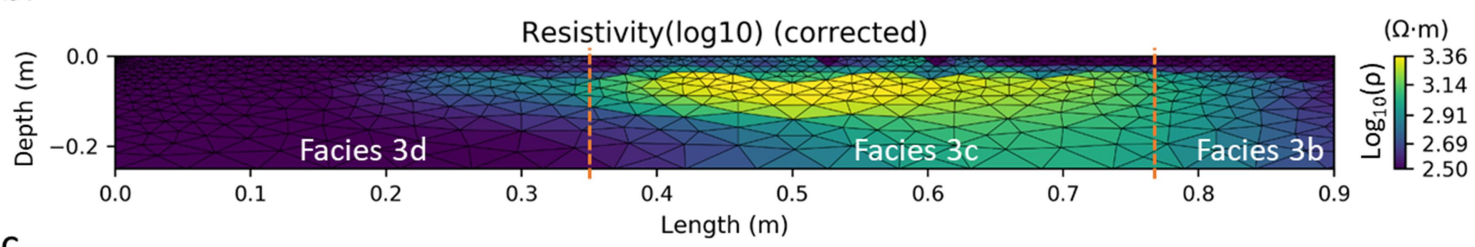

C.

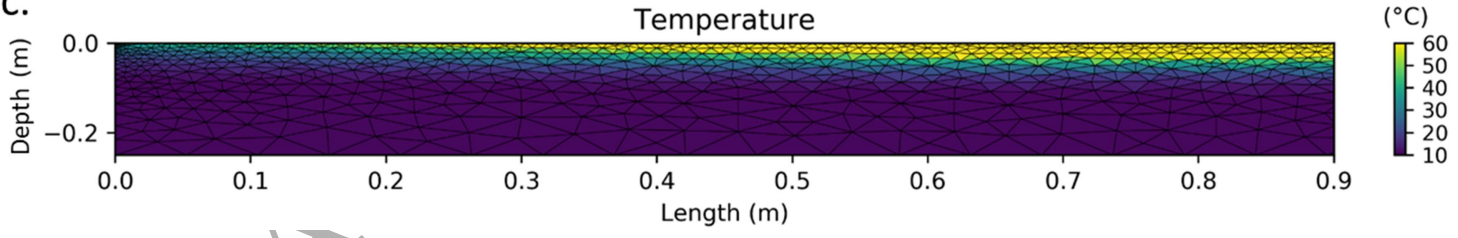

Figure 5: Inverted resistivity $46 \mathrm{~min}$ after ignition (a) before correction (RRMS (Relative Root-Mean Square $)=7.3 \%)$, (b) after correction $\left(T_{\text {ref }}=25^{\circ} \mathrm{C}\right)$. (c) Modeled temperature, evolving during the 5-minute measurement. The three geological facies cut by the profile are shown in (b).

Note that we corrected the whole profile and then focused on the center part, facies 3c (Figure 5.b and Figure 2), as it was the best sampled one with the best overall sensitivity. However, there were slight 
differences which remained significant. For example, the first $3 \mathrm{~cm}$ had a very low resistivity which appeared to be a little higher after correction, thus it was underestimated without correction. Deeper in the profile, at approximately $20 \mathrm{~cm}$, the resistivity was higher before correction than after because the rock mass temperature (approx. $12^{\circ} \mathrm{C}$ ) was lower than that of the reference temperature $\left(25^{\circ} \mathrm{C}\right.$ ).

The resistivity data presented below are all corrected for the temperature effect using this methodology.

\section{Results}

The correction methods detailed earlier are applied to all the profiles measured during the fire (representing 27 images). The median resistivity is calculated for nine 2-centimeter-thick intervals, along the entire facies $3 c$, and will be mentioned by the location of its middle point along the paper.

Figure 6.a displays the resistivity data variations from $25 \mathrm{~h}$ (1534 $\mathrm{min}$ ) before to $21 \mathrm{~h}$ (1290 $\mathrm{min}$ ) after the fire ignition. Figure $6 \mathrm{~b}$ details the variation from the ignition to $7 \mathrm{~h}$ later $(423 \mathrm{~min})$. Each curve represents the median resistivity in an interval of $2 \mathrm{~cm}$, denoted by its middle point. Before the fire, the resistivity distribution (e.g. Figure 5.b and Verdet et al. (2018)) can be described as follows (Figure 6.a): between depths of 0 and $0.03 \mathrm{~m}$, resistivity is low (blue in Figure 6.a), between 0.03 and $0.14 \mathrm{~m}$ (red in Figure 6.a), resistivity is higher, and deeper than $0.14 \mathrm{~m}$ (green in Eigure 6.a), resistivity is medium. The resistivity globally increases on the profile and the highest resistivity is found between 0.03 and $0.08 \mathrm{~m}$ at $52.5 \mathrm{~min}$ and $423 \mathrm{~min}$ after ignition, reaching $2500 \Omega \mathrm{m}$ (Figure 6.a). The resistivity then globally decreases from $423 \mathrm{~min}$ to the last measurement at $1280 \mathrm{~min}$. At $1280 \mathrm{~min}$, the initial state is almost reached, with less than $10 \%$ difference in resistivity, except at $0.03 \mathrm{~m}$ where the resistivity increases by $20 \%$.

Figure 7.a displays the median resistivity against depth for five selected times. At each depth, the median resistivity almost returns to its initial state after the fire (deep blue and yellow curves in Figure 7.a), except, as mentioned earlier, at $0.03 \mathrm{~m}$. Compared to the initial state, the curve $36.7 \mathrm{~min}$ after ignition (Figure 7.a) presents a higher resistivity close to the surface and a lower resistivity deep in the profile. The curves at $46.8 \mathrm{~min}$ and $\mathbf{5 2 . 5} \mathrm{min}$ (fire supply stops) present the same resistivity as that at 36.7 min near the surface, and a higher one deeper. Figure 7.b. displaying spatial derivatives, a slope increase means that the difference between the resistivity at 0.10 and $0.18 \mathrm{~m}$ increases, while a slope decrease means that the difference between the resistivity at 0.10 and $0.18 \mathrm{~m}$ decreases. The slope of the resistivity curves calculated on the $0.10-0.18 \mathrm{~m}$ portion (Figure $7 . \mathrm{b}$ ) is always negative. This means 
the resistivity at 0.10 is always higher than that at $0.18 \mathrm{~m}$. It decreases abruptly at the beginning of the fire until $46.8 \mathrm{~min}$, i.e. when the fire supply is ending; increases until $114 \mathrm{~min}$, and then decreases again until $542 \mathrm{~min}$ before returning to its initial value (Figure 7.b). This means that the resistivity dynamics changes three times: at $46.8 \mathrm{~min}$, at $114 \mathrm{~min}$ and at $542 \mathrm{~min}$.

In detail, resistivity variations can be classified in two groups (Figure 6.b). The given depth corresponds to the middle of each interval and should be read with $\mathrm{a} \pm 0.01 \mathrm{~m}$ precision.

- from $0.01 \mathrm{~m}$, resistivity increases until the fire supply stops, after that it remains constant and then diminishes slowly until the initial resistivity is reached. The inertia of the fire effect penetrating the rock is observed and measured as the curves from 0.03 to $0.09 \mathrm{~m}$ show the same pattern with a delay increasing with depth.

- Between 0.11 and $0.17 \mathrm{~m}$, resistivity varies likewise. Resistivity decreases around 7/min after the fire starts, stabilizes and finally increases until after the fire supply stops where it becomes stable. It then decreases again slowly until its initial state. 
a.

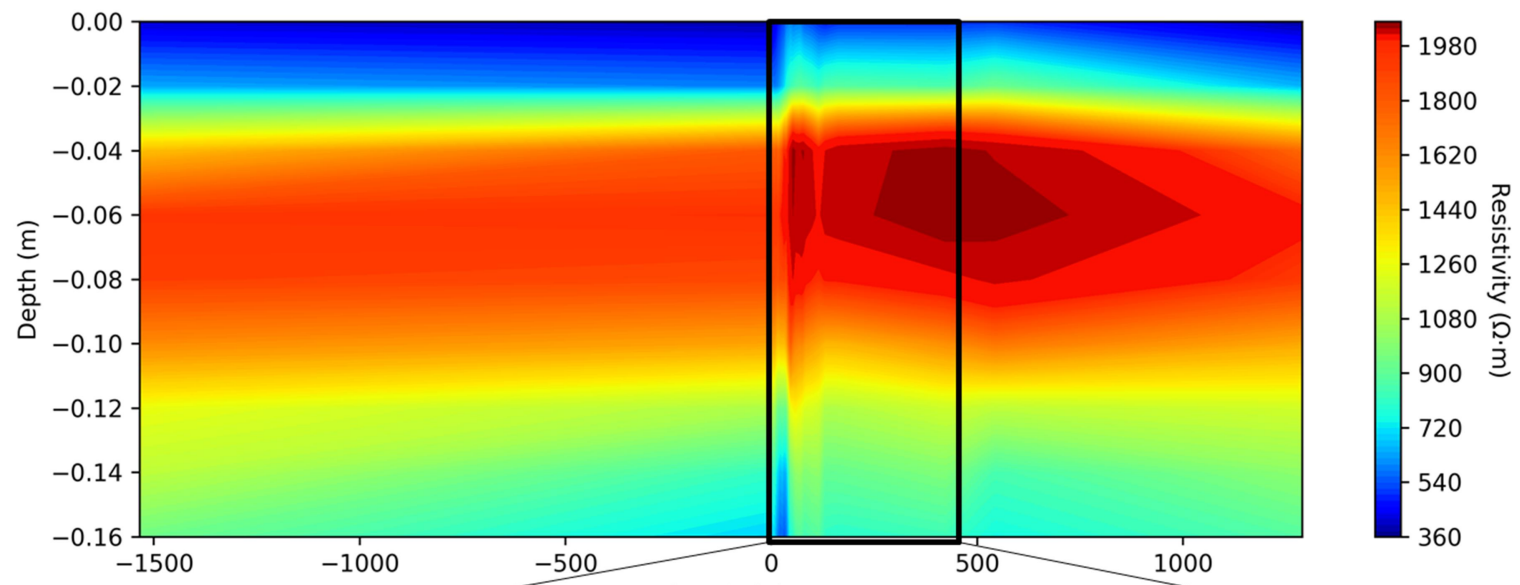

b.

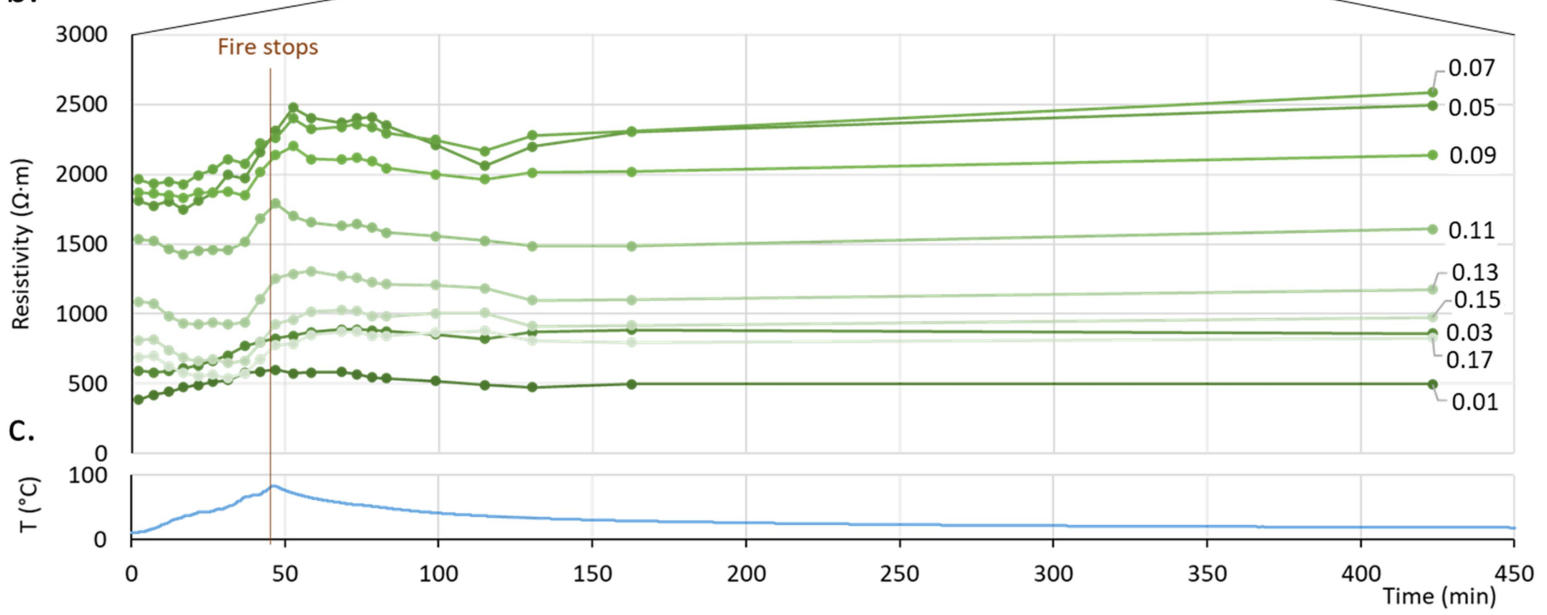

Figure 6 : (a) Resistivity variations with time and depth in the profile. (b) detailed description of the resistivity variation from the ignition to $7 \mathrm{~h}$ later $(423 \mathrm{~min})$. Each curve represents the median resistivity in an interval of $2 \mathrm{~cm}$, denoted with its middle point. A measurement was done approximately every $5 \mathrm{~min}$. (c) Temperature measured at thermocouple T4 (located at $1.5 \mathrm{~cm}$ in depth). 

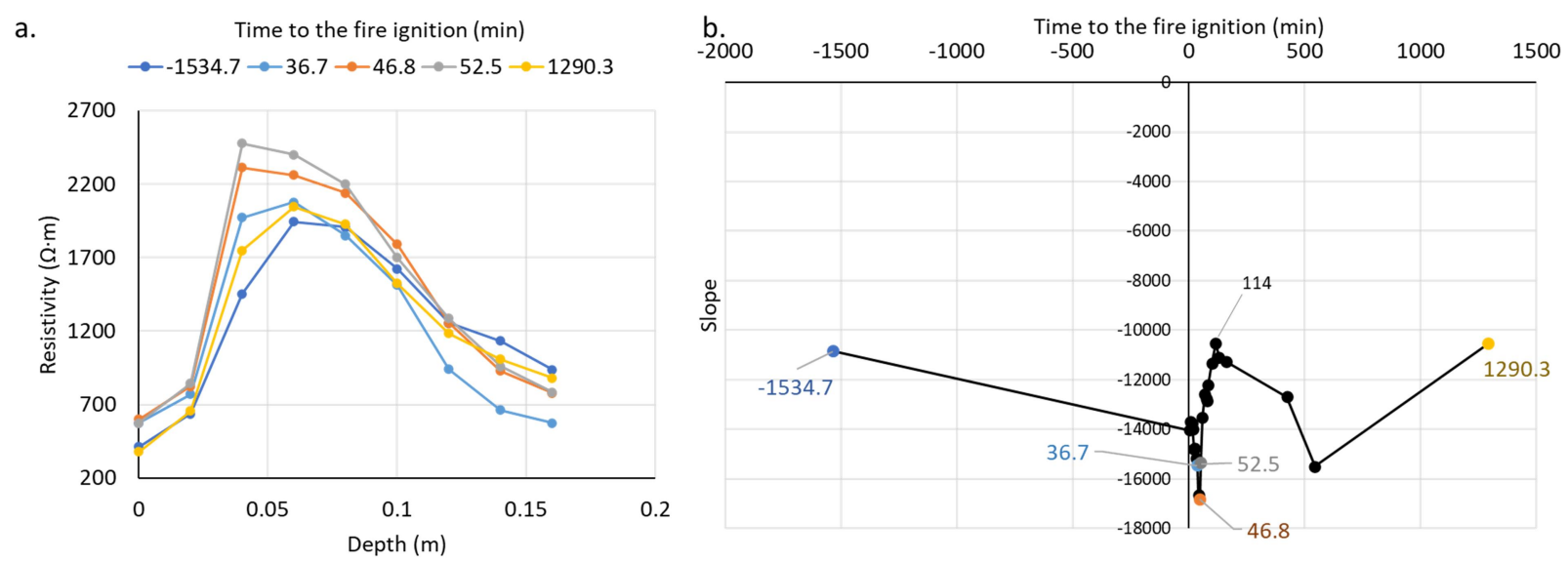

Figure 7: (a) Variation of the resistivity with depth at five times before, during the fire and after the fire supply stops. (b) evolution of the curve slopes (i.e., spatial derivative of the resistivity) from 0.10 to 0.18 $m$ depth. The slopes of the five curves displayed in (a) are emphasized with their corresponding color.

\section{Discussion}

The variation of resistivity with time can reflect changes in water saturation, ionic contents or even phase changes. As calcite has a retrograde solubility (crystalize when temperature increases), the ionic content would decrease, inducing an increase of the resistivity (Violette et al. 2016). We observed a decrease of resistivity and the temperature would not be high enough in the rock mass to cause phase changes. However, the structure of the rock could change (i.e., porosity, mechanicals properties). A change in porosity could mean a change in water content, but not necessarily in degree of saturation. Measurements of porosity on samples showed an increase in porosity from $40.3 \%$ to $43 \%$ near the surface $(2 \mathrm{~cm}$ ) and from $40 \%$ to $41.3 \%$ at $10 \mathrm{~cm}$ (Verdet 2019). According to Archie law (Archie 1942) an increase of $3 \%$ of porosity leads to a resistivity decrease of $10 \%$, and an increase of $1 \%$ of the porosity leads to a decrease of less than $5 \%$ of resistivity. The only decrease in resistivity observed is of $13 \%$ at $11 \mathrm{~cm}$ at the beginning of the fire. Therefore, the increase of only $1 \%$ in porosity at this depth could not fully explain the resistivity decrease, hence an increase in saturation. Everywhere else, the resistivity increases during the fire, which could not be explained by the changes in porosity. Therefore, in this study, the resistivity variations seem to reflect mainly the degree of saturation of rock. This hypothesis is endorsed for the following discussion.

The changes in degree of water saturation could be divided into five steps: 
1- From 0 to $16 \mathrm{~min}$, the surface (from 0 to $0.03 \mathrm{~m}$ ) water saturation degree decreases, while it stays stable at mid-depth (0.03-0.11 m). Deeper (0.11-0.17 m), saturation increases with a 7-min lag from fire ignition.

2- From 16 to 36.7 min the surface continues to dry while it stabilizes at mid-depth. Deeper, saturation decreases slowly.

3- From 36.7 to $46 \mathrm{~min}$ (i.e. to the fire supply stops), the whole profile presents a decrease in water saturation.

4- From $46 \mathrm{~min}$ to $114 \mathrm{~min}$, the surface saturation increases immediately, while a lag is observed with depth. Saturation increases from $52.5 \mathrm{~min}$ at mid-depth, and from $58.3 \mathrm{~min}$ deeper.

5- After $114 \mathrm{~min}$, the surface saturation still increases to reach its initial state. At mid-depth, saturation decreases again before increasing to its initial point. Deeper, there are slight variations before the initial state of water saturation is reached.

The changes in degree of saturation in the rock mean that the water migrates dyring the fire. This migration of water is assessed to a depth of at least $20 \mathrm{~cm}$ :

- Between 0 and 16 min: the temperature increases quickly and the energy is still located near the surface. The surface dries out (until $0.03 \mathrm{~m}$ ), while the water content stays stable between $0.03 \mathrm{~m}$ and $0.11 \mathrm{~m}$. The water migrates from the further part of the rock mass toward the back part of the profile. This could result from an increase of water vapor pressure in the surface and mid-depth that would prevent the water to migrate to the surface.

- Between 16 and 46 min: the thermal energy reaches mid-depth and deep areas. Due to a large poral system (high porosity of $41 \%$ and high connectivity), the vapor water pressure could be released after $36 \mathrm{~min}$ and the water migrates from the deep areas to the surface where it evaporates. Such a pressure release could create micro-cracks as it was observed after the fires at 2-cm depth in Verdet (2019), leading to? an increase of porosity (Brotóns et al. (2013) also observed an increase of porosity on heated samples).

- After the fire supply stops, the temperature decreases slowly (Figure 4), and water could migrate from the air to the wall and/or from the rock mass to the surface, increasing the water saturation at the surface.

After $114 \mathrm{~min}$, begins a phase of readjustment of the water saturation in depth until its initial state. A hypothesis of this readjustment phase could be that there would not be enough water far in the rock mass to continue to supply water in depth of the profile (less than $0.18 \mathrm{~m}$ ). The resistivity would then 
increase until $542 \mathrm{~min}$. After, the water could be pumped from both far in the rock mass (deeper than $0.18 \mathrm{~m}$ ) and from the surface of the wall, towards the depth part of the profile (less than $0.18 \mathrm{~m}$ ). The water would then migrate from both the air of the gallery and from far in the rock mass, through a readjustment phase until it reaches its initial state. Furthermore, the increase of saturation deeper than $0.11 \mathrm{~m}$ (7 min after ignition) is unexpected as the saturation at the surface decreases. This might remind a moisture clog as described by others (Jansson \& Boström 2009, der Heijden et al. 2012, Mindeguia et al. 2015, Choe et al. 2019). Usually, a moisture clog forms during fast heating. It is due to the difference in pressure in the poral system that impeaches the water to migrate all through the sample toward the surface. A so-called supersaturated state is reached at a small depth, forming the moisture clog. However, the layer we observed was not saturated, but rather presents a higher saturation than near the surface and deeper than observed on samples (Choe et al. 2019). This deeper, higher saturatedarea, could be explained by the temperature reached in the rock near the ERT profile location that was lower than $100^{\circ} \mathrm{C}$ (Figure 6.c) but still subjected to fast heating. There might be three hypotheses for the early dissipation of the pressure. First, the heating regime might be too low, either the temperature is too low or the exposure time is too short. Second, the high porosity $(41 \%$ at $10 \mathrm{~cm})$ and the highly connected poral system of the Rupelian limestone would allow a quick dissipation of the potential over pressure, hence the dissipation of the moisture clog before it was fully formed. Third, the initial porosity is low enough for the pressure to increase and would initially act as a barrier for the water. Afterwards, the pressure would be too high against the rock strength, that would create micro-cracks and increase the porosity and the connectivity, leading to a pressure release. This last hypothesis is supported by porosity measurements done on samples exposed and not exposed to fires, with an increase of $1 \%$ (at 2-cm depth) to $3 \%$ (at 3-cm depth) (Verdet et al. 2018).

\section{Conclusions}

The innovative high resolution micro-ERT monitoring method at a centimetric scale to monitor water migration in a quarry wall during fires has been proved to be efficient with this study. Indeed, the measurement of the effect of fires is commonly developed on samples of concrete or rock in laboratories to estimate mechanical properties such as water saturation. To the authors knowledge, these kinds of measurements have never been achieved on the field, in a limestone gallery. To estimate the water circulation near the surface, we chose to develop a micro-TRE measurement and a processing method. We developed a methodology that corrects both the electrode effect and that of rapid temperature growth on resistivity. First, the correction of the electrode effect is necessary due to the 
size of the equipment: electrode of $4 \mathrm{~mm}$ diameter, $1.5 \mathrm{~cm}$ depth and with an interelectrode distance of $4 \mathrm{~cm}$. The correction consists in the use of an Equivalent Electrode Point (EEP) at $73 \%$ depth of the length of electrodes, as described in Verdet et al. (2018), giving an ERT image corrected from the electrode effect but not from the temperature effect. Second, the correction of the ERT from the temperature effect was done dynamically because of the duration of one measurement $(5 \mathrm{~min})$ which is long compared to the fire temperature rapid changes, following few steps : (1) modeling the temperature field of the quarry wall with time, adjusted on thermocouples measurements within the wall; (2) then creating a time matrix linking each ERT resistivity cell to a time from which a temperature matrix is created; (3) correcting the inverted resistivity cells from their modeled time-dependent temperature.

Once corrected, water migration within the $41 \%$ porous wall was assessed through resistivity. Three main phases were observed: (1) from 0 to $16 \mathrm{~min}$ after fire ignition, the surface dries and water accumulate deeper than $0.11 \mathrm{~m}$ - this could follow a pattern close to a moisture clog formation. (2) from 16 and $36 \mathrm{~min}$, the surface continues to dry while it stabilizes at mid-depth. Deeper, saturation decreases slowly (3) from 36 to $46 \mathrm{~min}$, the whole profile dries out and the water could migrate from deeper parts of the rock wall towards the surface where it evaporates; (4) after fire supply stops, at $46 \mathrm{~min}$, the water migrates from both the air of the gallery and from far in the rock, through a readjustment phase until it reaches its initial state.

The described process at $0.11 \mathrm{~m}$ could correspond to the beginning of a moisture clog formation in the rock mass. But the weak heating regime associated with the high porosity of Rupelian limestone could have mitigated this phenomenon before reaching its total expansion.

The fire, with a duration of $46 \mathrm{~min}$ in a confined area, increases noticeably the temperature to $35^{\circ} \mathrm{C}$ at $4.5 \mathrm{~cm}$. However, the effect of this fire, and particularly the quickly migration of water, is observed at least until $20 \mathrm{~cm}$ in the rock mass. In addition, fast water migration could have been sufficient to lead to alterations such as micro-cracking. A longer fire like in caves, tunnels or historical monuments could also affect the rock, due to the temperature and rapid migration of water at important depths. For instance, in mansory or concrete buildings, all the mechanical properties changes could imply recrystallization or micro-cracking. 


\section{Acknowledgments}

We used the fire experiment site funded by the Regional Council of Nouvelle-Aquitaine (CarMoThaP project). We thank Catherine Ferrier (PACEA) and Jean Claude Leblanc as leaders in the fire experiments. We thank Jean-Christophe Mindeguia for his help and for lending us the thermocouples, Martin Acebo for his help in programming, and Fabien Naessens and Sylvain Mateo for their help in the installation of the micro-ERT profile and monitoring. We thank the LCPP staff (Laboratoire Centrale de la Préfecture de Police) for their help in providing the experimental instrumentation. We thank $\mathrm{C}$. Bouchet, the owner of the quarry in Fauroux (Lugasson) and M. Vidal for providing scots pine, as well as the SDIS 33 staff for participation in the experiments.

Author contribution statement: $C$. Verdet and F. Salmon wrote the paper and developed the temperature correction algorithm; C. Verdet and C. Sirieix developed the resistivity survey, field acquisition, and ERT data analysis; C. Sirieix and D. Lacanette proof read the paper, D. Lacanette and F. Salmon developed the thermic algorithm.

\section{Data availability}

Dataset available at ZENODO: https://doi.org/10.5281/zenodo.3974137

\section{References}

Abraham, O. \& Dérobert, X.2003. Non-destructive testing of fired tunnel walls: the Mont-Blanc Tunnel case study. NDT E Int., 36, 411-418. doi:10.1016/S0963-8695(03)00034-3

Archie, G.E.1942. The electrical resistivity $\log$ as an aid in determining some reservoir characteristics. Trans. Am. Inst. Min. Metall. Pet. Eng., Vol. 146, pp. 54-62, Dallas.

Besson, A., Cousin, I., Dorigny, A., Dabas, M. \& King, D.2008. The temperature correction for the electrical resistivity measurements in undisturbed soil samples: analysis of the existing conversion models and proposal of a new model. Soil Sci., 173, 707-720. doi:10.1097/SS.0b013e318189397f 
Brotóns, V., Tomás, R., Ivorra, S. \& Alarcón, J.C.2013. Temperature influence on the physical and mechanical properties of a porous rock: San Julian's calcarenite. Eng. Geol., 167, 117-127. doi:10.1016/j.enggeo.2013.10.012

Campbell, R.B., Bower, C.A. \& Richards, L.A.1948. Change of electrical conductivity with temperature and the relation of osmotic pressure to electrical conductivity and ion concentration for soil extract. Soil Sci. Soc. Am. Proc., 13, 66-69. doi:10.2136/sssaj1949.036159950013000C0010x

Carrancho, Á., Villalaín, J.J., Angelucci, D.E., Dekkers, M.J., Vallverdú, J. \& Vergès, J.M.2009. Rockmagnetic analyses as a tool to investigate archaeological fired sediments: a case study of Mirador cave (Sierra de Atapuerca, Spain). Geophys. J. Int., 179, 79-96. doi:10.1111/j.1365246X.2009.04276.x

Choe, G., Kim, G., Yoon, M., Hwang, E., Nam, J. \& Guncunski, N.2019. Effect of moisture migration and water vapor pressure build-up with the heating rate on concrete spalling type. Cem. Concr. Res., 116, 1-10. doi:10.1016/j.cemconres.2018.10.021

Corwin, D.L. \& Lesch, S.M.2005. Apparent soil electrical conductivity measurements in agriculture. Comput. Electron. Agric., 46, 11-43. doi:10.1016/j.compag.2004.10.005

Deldicque, D. \& Rouzaud, J.-N.2020. Temperatures reached by the roof structure of Notre-Dame de Paris in the fire of April 15th 2019 determined by Raman paleothermometry. Comptes Rendus Géoscience, 352, 7-18. doi:10.5802/crgeos.9

Dubois, C., Lans, B., Kaufmann, O., Maire, R. \& Quinif, Y.2011. Karstification de type fantômes de roche en Entre-deux-Mers (Gironde, France) : implication en karstogenèse et morphologie karstique. Karstologia, 57, 19-27.

Ferrier, C., Bellivier, A., Lacanette, D., Leblanc, J.-C., Mindeguia, J.-C. \& Salmon, F.2017. L'utilisation du feu dans l'endokarst au Paléolithique : approche interdisciplinaire et expérimentale (programme CarMoThaP). Karstologia, 23-32. 
Genelle, F., Sirieix, C., Riss, J. \& Naudet, V.2012. Monitoring landfill cover by electrical resistivity tomography on an experimental site. Eng. Geol., 145-146, 18-29. doi:10.1016/j.enggeo.2012.06.002

GESA.2015. GESA, 25 ans d'explorations souterraines en Gironde., Groupe d'explorations spéléologiques d'Aquitaine.

Grolier, J., Fernandez, A., Hucher, M. \& Riss, J.1991. Les propriétés physiques des roches: théories et modèles, Paris: Masson.

Günther, T., Rücker, C. \& Spitzer, K.2006. Three-dimensional modelling and inversion of dc resistivity data incorporating topography - II. Inversion. Geophys. J. Int., 166, 506-517. doi:10.1111/j.1365246X.2006.03011.x

Hajpal, M. \& Török, A.2004. Mineralogical and colour changes of quartz sandstones by heat. Environ. Geol., 46. doi:10.1007/s00254-004-1034-z

Hayley, K., Bentley, L.R. \& Pidlisecky, A.2010. Compensating for temperature variations in time-lapse electrical resistivity difference imaging. GEOPHYSICS, 75, WA51-WA59. doi:10.1190/1.3478208

Heijden, G.H.A. van der, Pel, L. \& Adan, O.C.G.2012. Fire spalling of concrete, as studied by NMR. Cem. Concr. Res., 42, 265-271. doi:10.1016/j.cemconres.2011.09.014

Jansson, R. \& Boström, L.2009. Fire spalling - the moisture effect. 1st Int. Workshop Concr. Spalling Due Fire Expo. - Real Life Exp. Pract. Appl. Lab-Scale Investig. Numer. Model., pp. 120-129, MFPA Institute Leipzig, Germany.

Karato, S. \& Wang, D.2013. Electrical conductivity of minerals and rocks. in Physics and Chemistry of the Deep Earth, John Wiley and Sons Ltd., pp. 145-182.

Keller, G. \& Frischknecht, F.1966. Electrical methods in geophysical prospecting., Pergamon Press., Oxford, UK. 
Lacanette, D., Mindeguia, J.-C., Brodard, A., Ferrier, C., Guibert, P., Leblanc, J.-C., Malaurent, P., et al.2017. Simulation of an experimental fire in an underground limestone quarry for the study of Paleolithic fires. Int. J. Therm. Sci., 120, 1-18. doi:10.1016/j.ijthermalsci.2017.05.021

Le Pochat, G. \& Sellier, E.1980. Les calcaires tendre de I'Entre-Deux-Mers. ( No. 80 SGN 226 AQI), p. 17, Pessac: BRGM - Service Géologique Régional d’Aquitanie.

Ma, R., McBratney, A., Whelan, B., Minasny, B. \& Short, M.2011. Comparing temperature correction models for soil electrical conductivity measurement. Precis. Agric., 12, 55-66. doi:10.1007/s11119-009-9156-7

McCabe, S., Smith, B.J. \& Warke, P.A.2010. Exploitation of inherited weakness in fire-damaged building sandstone: the 'fatiguing' of 'shocked' stone. Eng. Geol., 115, 217-225. doi:10.1016/j.enggeo.2009.06.003

Mindeguia, J.-C., Carré, H., Pimienta, P. \& La Borderie, C.2015. Experimental discussion on the mechanisms behind the fire spalling of concrete. Fire Mater., 39, 619-635. doi:10.1002/fam.2254

Nassif, A.Y., Yoshitake, I. \& Allam, A.2014. Full-scale fire testing and numerical modelling of the transient thermo-mechanical behaviour of steel-stud gypsum board partition walls. Constr. Build. Mater., 59, 51-61. doi:10.1016/j.conbuildmat.2014.02.027

Nguyen, T.-D., Meftah, F., Chammas, R. \& Mebarki, A.2009. The behaviour of masonry walls subjected to fire: Modelling and parametrical studies in the case of hollow burnt-clay bricks. Fire Saf. J., 44, 629-641. doi:10.1016/j.firesaf.2008.12.006

Or, D. \& Wraith, J.M.1999. Temperature effects on soil bulk dielectric permittivity measured by time domain yreflectometry: A physical model. Water Resour. Res., 35, 371-383. doi:10.1029/1998WR900008 
Ozguven, A. \& Ozcelik, Y.2014. Effects of high temperature on physico-mechanical properties of Turkish natural building stones. Eng. Geol., 183, 127-136. doi:10.1016/j.enggeo.2014.10.006

Rhoades, J.D., Kaddah, M.T., Halvorson, A.D. \& Prather, R.J.1977. Establishing soil electrical conductivity-salinity calibration using four-electrode cells containing undisturbed soil cores. Soil Sci., 123, 137-141.

Richards, L.A.1969. Diagnosis and improvement of saline and alkali soils, United States Department Of Agriculture; Washington.

Salmon, F., Ferrier, C., Lacanette, D., Mindeguia, J.-C., Leblanc, J.-C., Fritz, C. \& Sirieix, C.2020a. Numerical Reconstruction of Paleolithic Fires in the Chauvet-Pont d'Arc Cave (Ardèche, France). J. Archaeol. Method Theory. doi:10.1007/s10816-020-09484-5

Salmon, F., Lacanette, D., Mindeguia, J.-C., Sirieix, C., Bellivier, A., Leblanc, Y.-C. \& Ferrier, C.2020b. Development of a Fluid-Structure Coupling Validated with a Confined Fire: Application to Painted Caves. Fire Technol., 56, 1197-1227. doi:10.1007/s10694-019-00926-5

Salmon, F., Lacanette, D., Mindeguia, J.-C., Sirieix, C., Bellivier, A., Leblanc, J.-C. \& Ferrier, C.2019. Localized fire in a gallery: Model development and validation. Int. J. Therm. Sci., 139, 144-159. doi:10.1016/j.ijthermalsci.2019.01.025

Shao, Z., Wang, D., Wang, Y., Zhong, X., Tang, X. \& Xi, D.2016. Electrical resistivity of coal-bearing rocks under high temperature and the detection of coal fires using electrical resistance tomography. Geophys. J. Int., 204, 1316-1331. doi:10.1093/gji/ggv525

Sheets, K.R. \& Hendrickx, J.M.H.1995. Noninvasive soil water content measurement using electromagnetic induction. Water Resour. Res., 31, 2401-2409.

Verdet, C.2019. Caractérisation multi-échelle du milieu karstique non saturé, Thèse de Doctorat, Bordeaux, Université de Bordeaux. 
Verdet, C., Anguy, Y., Sirieix, C., Clément, R. \& Gaborieau, C.2018. On the effect of electrode finiteness in small-scale electrical resistivity imaging. Geophysics, 83, 39-52. doi:10.1190/geo2018-0074.1

Violette, S., Collin, P.-Y., Lagneau, V., Aubertin, F., Makhloufi, Y., Charton, R. \& Bergerat, F.2016. Reactive transport modelling of carbonate cementation in a deep saline aquifer, the Middle Jurassic Oolithe Blanche Formation, Paris Basin, France. Comptes Rendus Geosci., 348, 540-549. doi:10.1016/j.crte.2016.06.002

Wang, F., Frühwirt, T., Konietzky, H. \& Zhu, Q.2019. Thermo-mechanical behaviour of granite during high-speed heating. Eng. Geol., 260, 105258. doi:10.1016/j.enggeo.2019.105258

Wells, C.B.1978. in Electrolytic conductivity of soil solution and waters: conversions from conductance measurements at field temperatures Division of Soils Technical, pp. 1-17, Melbourne: CSIRO.

Wessling, S., Kessels, W., Schmidt, M. \& Krause, U.2008. Investigating dynamic underground coal fires by means of numerical simulation. Geophys. J. Int., 172, 439-454. doi:10.1111/j.1365246X.2007.03568.x

Whitney, M. \& Briggs, L.J.1897. in An electrical method of determining the temperature of soils., USDA Division of soil Buletin., Vol. 7, pp. 1-15, Washington D.C.

Xu, S., Sirieix, C., Ferrier, C., Lacanette-Puyo, D., Riss, J. \& Malaurent, P.2015. A geophysical tool for the conservation of a decorated cave - a case study for the Lascaux cave. Archaeol. Prospect., 22, 283-292. doi:10.1002/arp.1513

Zhao, B. \& Kruppa, J.2004. Structural behaviour of an open car park under real fire scenarios. Fire Mater., 28, 269-280. doi:10.1002/fam.867 